\title{
Effects of eccentric exercise-induced delayed onset muscle soreness on endoplasmic reticulum stress-related markers
}

\section{[Eksantrik egzersize bağlı gecikmiş kas ağrısının endoplazmik retikulum stresle ilişkili belirteçler üzerindeki etkileri]}

https://doi.org/10.1515/tjb-2020-0014

Received January 10, 2020; accepted November 6, 2020;

published online December 22, 2020

\section{Abstract}

Short Communications: Apelin, pentraxin3 (PTX3), and interleukin6 (IL6) parameters are known as inflammation markers and found to be related to endoplasmic reticulum (ER) stress. The aim of the study was to investigate the effect of eccentric exercise-induced delayed onset muscle soreness (DOMS) on ER stress-related markers in young athletes. Objectives and Methods: ER stress and DOMS-related blood markers, maximal strength level, and rate of perceived exertion using the visual analog scale (VAS) were assessed before, immediately after, 24, 48, and $72 \mathrm{~h}$ after the muscle damage protocol.

*Corresponding author: Gulbin Rudarli Nalcakan, Department of Coaching Education, Faculty of Sport Science, Ege University, Izmir, Turkiye, E-mail: gulbinrn@gmail.com. https://orcid.org/0000-00018914-7479

Yeliz Dogru, Izmir Katip Celebi University, Rectorate, Izmir, Turkiye, E-mail: yeliz.dogru@hotmail.com. https://orcid.org/0000-00032358-3782

S Rana Varol, Department of Coaching Education, Faculty of Sport Science, Ege University, Izmir, Turkiye, E-mail: ranavarol@gmail.com Murat Akyuz and Murat Tas, Department of Coaching Education, Faculty of Sport Science, Manisa Celal Bayar University, Manisa, Turkiye, E-mail: sporcu006@gmail.com (M. Akyuz), murat.tas@cbu.edu.tr (M. Tas)

Cevval Ulman, Department of Biochemistry, Faculty of Medicine, Manisa Celal Bayar University, Manisa, Turkiye,

E-mail: cevval.ulman@gmail.com

Әopen Access. @ 2020 Yeliz Dogru et al., published by De Gruyter. (c) BY License.
Results: IL6 peaked $24 \mathrm{~h}$ after while creatine kinase and lactate dehydrogenase enzyme levels reached their peaks at $72 \mathrm{~h}$ after the protocol. The level of apelin continued to increase throughout the four measurements, and PTX3 peaked at $24 \mathrm{~h}$, and then declined to the levels before the protocol but the differences were not significant. The significant decrease in the strength and the significant increase in VAS continued $48 \mathrm{~h}$ after the protocol.

Conclusion: ER is activated and ER stress occurred, due to increases in IL6, PTX3 and apelin levels after the test protocol concluded that a single vigorous eccentric exercise should be avoided in harmful effect on health as parallel with Physical Activity Guidelines.

Keywords: apelin; creatine kinase; eccentric exercise; interleukin6; muscle damage; pentraxin3.

Öz

Giriş: Apelin, pentraxin 3 (PTX3) ve interlökin 6 (IL6) parametreleri inflamasyon belirteçleri olarak bilinir ve endoplazmik retikulum (ER) stresi ile ilişkili olduğu bulunmuştur. $\mathrm{Bu}$ çalışmanın amacı, eksentrik egzersize bağlı gecikmiş kas ağrısının (DOMS) genç sporcularda ER stres ile ilişkili belirteçler üzerindeki etkisini araştırmaktı. Materyal ve yöntem: ER stresi ve DOMS ile ilgili kan belirteçleri, maksimum kuvvet düzeyi ve görsel analog ölçeği (VAS) kullanılarak algılanan efor oranı, izokinetik dinamometrede eksantrik kasılmalar ile oluşturulan kas hasarı protokolünden önce, hemen sonra, 24, 48 ve 72 saat sonra değerlendirildi. 
Bulgular: IL6 DOMS protokolünden 24 saat sonra, kreatin kinaz (CK) ve laktat dehidrojenaz (LDH) enzim seviyeleri 72 saat sonra zirve yaptı. Apelin seviyesi dört ölçüm boyunca artmaya devam etti ve PTX3 24 saatte zirve yaptı, ardından protokolden önceki seviyelere düştü ancak farklar anlamlı değildi. Maksimal kuvvetteki önemli düşüş ve VAS'daki önemli artış protokolden 48 saat sonra devam etti.

Sonuç: Kas hasar testi protokolünden sonraki mevcut gözlemler IL6, PTX3 ve apelin düzeylerindeki artışlara bağlı olarak ER'nin aktive olduğunu ve ER stresinin oluştuğunu göstermektedir. Fiziksel Aktivite Rehberine paralel olarak, tek bir şiddetli eksentrik egzersizden sağlık üzerinde zararlı etkisi nedeniyle kaçınılması gerektiği sonucuna varılmıştır.

Anahtar Kelimeler: apelin; kreatin kinaz; eksentrik egzersiz; interlökin 6; kas hasarı; pentraksin3.

\section{Introduction}

Endoplasmic reticulum (ER) within the cytoplasm of eukaryotic cells is the main organelle that serves the roles of free intracellular calcium storage, lipid synthesis, protein folding, processing and transport to the location it would function as well as ensuring protein quality control through this process [1]. The newly synthesized proteins that enter into the ER fold after undergoing four phases with a high error probability (N-glycosylation, disulfide bond formation, hydroxylation, oligomerization). However, many factors such as calcium balance upset, hypoxia, oxidative stress, infection and heat stress may have negative effects on protein folding. This, in turn, causes ER homeostasis disturbance and unfolded or misfolded protein formation. This process is called ER stress.

A set of intracellular signaling pathways called unfolded protein response (UPR) is activated in order to prevent, correct ER stress or rehabilitate the homeostasis. UPR is a preventive response developed to improve protein folding capacity against ER stress, reduce misfolding and ensure homeostasis. The presence of a high number of misfolded proteins within ER despite this response may incapacitate the responses to stress. In such cases, the cell is triggered for apoptosis in order to avoid damage to the surrounding tissue. There are several cell death pathways that are considered to mediate the initiation of apoptosis with ER stress [2].

Besides being an adipocytokine, apelin is a neuropeptide and a cardiovascular peptide as well. Studies show that apelin regulates the apoptosis caused by ER stress being activated through UPR signaling pathways $[3,4]$. Among acute phase proteins, interleukin 6 (IL6) and pentraxin 3 (PTX3), are those which are produced by many cells and rapidly increase at early phases of inflammation [5, 6]. Studies report that ER stress-related inflammation causes IL6 increase [7, 8], while PTX3 increase may be an important preventer from ER stressrelated cell death [9]. While exercise-based studies have found controversial results concerning apelin [10, 11], PTX3 [12] and IL6 [13] have been shown to begin increasing with high-intensity exercise.

It can be seen in the related literature that ER stress has been studied in terms of its effects on many metabolic diseases as well as neural, inflammatory response and age-related degenerations. Although it plays significant roles in metabolic regulation, it is seen there is a limited number of studies on the ER stress interaction of the skeletal muscle and that studies available have looked at the curative effect of regular exercise resulting from the adaptation of skeletal muscles by employing regular exercise method. Since such diseases are also often linked to the presence of abnormal or unfolded proteins, one mechanism for the protective effects of exercise may be through activation of the UPR to increase the capacity to deal with unfolded proteins. Despite having a limited secretion function, skeletal muscle is intriguing in terms of UPR since it contains an extremely wide specialized ER network called sarcoplasmic reticulum [14].

Skeletal muscle is damaged and inflamed depending on the duration and intensity of the increased physical work capacity. The long-lasting impairment in muscle performance has been referred to exerciseinduced muscle damage, which causes an increase in inflammatory markers in the blood, associated with an increase of edema and delayed onset muscle soreness (DOMS), as well as a prolonged impairment in muscle strength, and range of motion. DOMS develops within 8-72 h following the unaccustomed and/or eccentric exercises, generally peaks in $24-48 \mathrm{~h}$ and disappears in 5-10 days [15]. To the best of our knowledge, there is only one previous study showing that there is a relationship between DOMS and ER stress with the increase of ER stress proteins involved in UPR activation in the working muscles of the rats [16].

Thus, the aim of the present study was to investigate the effect of DOMS after the eccentric exercise by measuring apelin, PTX3 and IL6 levels on the inflammatory mechanisms and possible endoplasmic reticulum stress in the athletes. It was hypothesized that apelin, PTX3, IL6, creatine kinase (CK) and lactate dehydrogenase (LDH) levels would increase following exercise-induced muscle damage, and there would be significant relationships between them. 


\section{Methods}

\section{Participants}

Eighteen healthy male football players from the U19 soccer league (training age: $7.83 \pm 1.15$ years, age: $18.8 \pm 0.43$ years, mass: $70.5 \pm 6.78 \mathrm{~kg}$, height: $180 \pm 5.13 \mathrm{~cm}$; body mass index (BMI): $21.8 \pm 1.66 \mathrm{~kg} \mathrm{~m}^{2}$, percentage of body fat (BF\%): $8.51 \pm 1.8 \%$ ) volunteered to participate in this investigation. All participants were active and were not following any specific diet regimen, nor chronically using medications or any supplements.

The subjects' rights were protected and written informed consents were obtained before the procedures according to the Helsinki Declaration. The experimental protocol was approved by the Local Scientific Research Ethics Board (approval no: 13/07/2016-20478486/ 278).

\section{Experimental design}

The repeated measures study design was used for this prospective laboratory experiment. Body mass and height were evaluated by an electronic scale (Seca 767, USA) and body fat \% was measured by a body analyzer (Tanita, Body Composition Analyzer, BC-418, Tokyo, Japan) with overnight fasting. Muscle soreness protocol and maximal strength test measurements were performed using an isokinetic dynamometer (Isoforce, TUR Gmbh, Berlin, Germany). Blood samples were taken from all participants 5 times in total: before, immediately after, 24,48 , and $72 \mathrm{~h}$ after the muscle soreness protocol. Maximal strength test was performed after blood withdrawal and the perceived exertion level was assessed by a visual analog scale (VAS) [4, 18]. The participants were instructed not to attend any physical activities, not to change their diets during the study period.

\section{Maximal strength test}

On each test day (4 days in total), the isokinetic dynamometer device was calibrated prior to measurements. Volunteers were fixed to the device with the help of apparatus in a sitting position without moving their femurs and chests. The rotation axis of the dynamometer was adjusted for each participant's height (lateral/femoral condyle). The test was conducted by measuring the maximal concentric strength output (peak torque- PT) during the 6 repeated knee flexionsextensions performed with the dominant leg at an angular velocity of $60 \% \mathrm{~s}$ and the highest peak torque value obtained from the repetitions was recorded [19]. The participants were provided with verbal motivation during the test by the researchers. Maximal strength tests were performed 5 times in total for the subsequent 4 days, between 09:30 and 10:30, as before, immediately after and at the 24th, 48th and $72 \mathrm{nd}$ hours after the muscle soreness protocol.

\section{Muscle soreness protocol}

The protocol consisted of repeated 6 sets x 10 unilateral eccentric/ concentric actions of knee flexors at an angular velocity of $60 \%$ s. The participants were told to put maximum effort during the eccentric phase of each knee flexion and to take their legs back to the initial positions during the concentric phase. $45 \mathrm{~s}$-recovery periods were allowed between sets. This protocol, aiming to create damage on the hamstring muscle of the dominant leg was previously used by Cockburn et al. and Harrison and Gaffney [19, 20].

\section{Blood analysis}

Venous blood samples $(9 \mathrm{~mL})$ were taken in a sterile vacutainer tube by a phlebotomist between 09:00 and 09:30 in the morning. Serum was separated by centrifugation, and samples were stored at $-80{ }^{\circ} \mathrm{C}$ until a batch assay was performed for all samples. CK and LDH measurements on the Unicel DxC 800 Synchron Clinical System device from Beckmann Coulter (Ireland Inc.), kits with the spectrophotometric method were used in the analysis. Daily inner quality tests and monthly outer quality tests were done regularly by the lab experts.

Apelin levels in blood samples were assessed by Enzyme-Linked ImmunoSorbent Assay (ELISA) method with commercial kits (SigmaAldrich, Saint Louis, Mo, USA). The inter and intraassay coefficient of variation (CV) for apelin at level $5.84 \mathrm{pg} / \mathrm{mL}$ were $<15 \%$ and $<10 \%$, respectively. PTX3 levels in blood samples were examined by the ELISA method with commercial kits (R\&D Systems Bio-Techne, Minneapolis, USA). The inter and intraassay CV for PTX3 at level $0.025 \mathrm{ng} /$ $\mathrm{mL}$ were 6.2 and $3.8 \%$, respectively. IL6 levels in blood samples were examined by the ELISA method with commercial kits (Diaclone Sas, Besancon, Cedex, France). The inter and intraassay CV for IL6 at level $2 \mathrm{pg} / \mathrm{mL}$ were 7.7 and $3.6 \%$, respectively.

\section{Statistical analyses}

Statistical analyses were conducted on the SPSS (version 23.0, SPSS Inc, Chicago, IL, USA) statistical package program. For normality (Shapiro-Wilk) testing, the Friedman F and Dunn-Bonferroni post hoc tests were used to compare repeated measures of the group. Because of the normally distributed data, repeated measures ANOVA and the Bonferroni post hoc procedure were performed only for the repetitive maximal strength (peak torque) test result, and the effect size of the difference was evaluated using the classification of Cohen $(<0.2$ trivial, $0.2 \leq \mathrm{d}<0.5$ small, $0.5 \leq \mathrm{d}<0.8$ moderate, $\mathrm{d} \geq 0.8$ large effect size). The Spearman Rank Correlation Coefficient Test was used to determine the level of correlation between the change ratios (\%) data according to the measurement of before the test. Descriptive statistics were reported as the mean \pm SD. The level of statistical significance was set at $\mathrm{p} \leq 0.05$.

The sample size was calculated on the basis of the previously reported the mean change of the PT values measured in the isokinetic dynamometer in the study conducted by Cockburn et al. [19]. Power analysis using a power of $80 \%$ and a significance of $\mathrm{p}=0.05$ showed that at least 10 subjects had to be recruited to detect a minimum clinically significant difference of PT score between the measures, when the mean expected value in the first measure was 123 with a standard deviation of 3 and the mean expected value in the second measure was 115 with a standard deviation of 5 . The possibility of drop out during the study period, the sample size taken was 18 .

\section{Results}

All parameters of participants measured before (1), immediately after (2), $24 \mathrm{~h}$ (3), $48 \mathrm{~h}$ (4), and $72 \mathrm{~h}$ after (5) the 
exercise protocol are shown in Table 1. The results obtained from the 1st and 2nd measures showed a non-significant increase for apelin and PTX3, a significant increase in IL6, CK, LDH levels and VAS $(\mathrm{p}<0.05)$ and a significant decrease in PT as the strength test results $[F=34.679, p<0.000$, $\left.\eta \rho^{2}=0.671\right]$. The significant difference was found in all parameters except PTX3 and apelin in the repeated measures. It was seen that PTX3 and IL6 levels reached their maximum levels (peak) in the measurements at the 24th hour; and apelin, CK, and LDH level at the 72nd hour.

Change ratios (\%) according to the measurement of before the test for all parameters were calculated using formula: $2-1 / 1 \times 100$. According to the results, CK increased 28.6,132, 181, and 135\%; LDH increased 19.4, 22.4, 94.7, and $161 \%$; apelin changed $0.8 \%,-0.3,1.1$, and $1.5 \%$; PTX3 increased 32,110.7, 42.3, and 23\%; IL6 increased 87, 99, 69.6, and $94 \%$; VAS also increased dramatically 1069, 1887, 2142, $2073 \%$, while PT decreased $-16.6 \%,-24.2 \%,-26.5 \%$, and $-18.3 \%$ respectively (Figure 1 ).

There were significant correlations between change ratios (\%) according to the first of repeated measurements for all parameters shown in Table 2.

\section{Discussion}

The aim of the present study is to examine the effects of the eccentric exercise-induced DOMS on apelin, PTX3, and IL6 parameters which are known as inflammation markers and are found to be related to ER stress as well. However, no study has been found on the relationship between DOMS and ER stress in the related literature.

The only study related to the aim of our research, carried out by Pereira et al. (2016) on ER stress and DOMS relationship suggested the hypothesis that excessive training model involving eccentric exercise may cause ER stress on the skeletal muscles (extensor digitorum longus

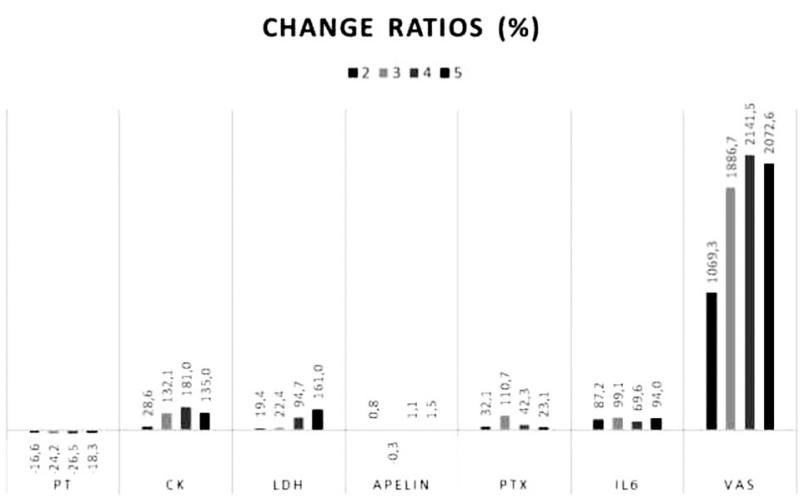

Figure 1: Change ratios (\%) according to the measurement of before the test for all parameters.

and soleus) of rats. They performed downhill and uphill level running protocols designed with similar external loadings (intensity with volume) for eight weeks on rats and examined ER stress proteins (BiP, ATF-6, pIRE1, pPERK, and peIF2alpha) that participate in UPR activation in the two-week recovery period. As a result, they stated that protein synthesis in the UPR pathways increased in both muscle groups examined in the downhill running group and that the values did not go back to normal in the recovery period, which confirmed their hypothesis [16].

It was seen in the literature review, that due to the negative relationship of apelin level with coronary artery diseases, particularly with endothelium dysfunction and the curative effects of regular aerobic exercise [17], apelin and exercise interaction has been studied on the elderly or individuals with metabolic diseases, especially diabetes; however, study results have revealed different findings. Apelin levels have been reported to increase significantly after eight-week aerobic training in the middle-aged and older group [17], after 12-week aerobic training in type two diabetes and overweight group [21], at the end of six months in the aerobic exercise group and aerobic and

Table 1: Changes in biochemical markers, muscle function, and perceived exertion following exercise-induced muscle damage (mean \pm SD).

\begin{tabular}{|c|c|c|c|c|c|c|}
\hline & before(1) & after(2) & $24 \mathrm{~h}$ after(3) & $48 \mathrm{~h}$ after(4) & $72 \mathrm{~h}$ after(5) & p-Value \\
\hline Apelin, pg/mL & $942 \pm 18.4$ & $949 \pm 21.6$ & $938 \pm 23.9$ & $952 \pm 17.4$ & $956 \pm 38.3$ & 0.053 \\
\hline PTX3, ng/mL & $1.67 \pm 0.69$ & $2.07 \pm 0.79$ & $2.94 \pm 2.14$ & $2.15 \pm 1.06$ & $1.86 \pm 0.87$ & 0.075 \\
\hline IL6, pg/mlL & $1.86 \pm 0.39$ & $3.35 \pm 1.90^{\Omega}$ & $3.49 \pm 1.92^{\Omega}$ & $3.02 \pm 1.01^{\Omega}$ & $3.46 \pm 0.96^{\Omega}$ & 0.003 \\
\hline $\mathrm{CK}, \mathrm{U} / \mathrm{L}$ & $236 \pm 150$ & $297 \pm 178$ & $882 \pm 696^{\Omega}$ & $3922 \pm 8804^{\Omega}$ & $12083 \pm 28110$ & 0.001 \\
\hline $\mathrm{LDH}, \mathrm{U} / \mathrm{L}$ & $178 \pm 23.6$ & $213 \pm 34.3^{\Omega}$ & $216 \pm 36.9^{\Omega}$ & $352 \pm 462^{\Omega}$ & $468 \pm 506^{\Omega}$ & 0.000 \\
\hline PT, Nm & $216 \pm 21.6$ & $179 \pm 16.6^{\Omega}$ & $163 \pm 22.4^{\Omega}$ & $158 \pm 31.7^{\Omega \beta}$ & $176 \pm 24.6^{\Omega}$ & 0.000 \\
\hline VAS $(1-10)$ & $0.15 \pm 0.17$ & $3.48 \pm 0.47$ & $5.41 \pm 0.38^{\Omega}$ & $6.26 \pm 0.39^{\Omega \beta €}$ & $5.93 \pm 0.35^{\Omega \beta}$ & 0.000 \\
\hline
\end{tabular}

PT, peak torque; PTX3. pentraxin 3; IL6, interleukin 6; CK, creatine kinase; LDH, lactate dehydrogenase; VAS, visual analog scale; $\Omega$ : shows statistically significance when compared to (1), $\beta$ : shows statistically significance when compared to (2), €: shows statistically significance when compared to (3). 
Table 2: Significant correlations between change ratios (\%) according to the first measurement for all parameters.

\begin{tabular}{|c|c|c|c|c|c|}
\hline & PTX3 & IL6 & CK & PT & VAS \\
\hline Apelin & $\begin{array}{l}\text { Apelin }_{3}-\mathrm{PTX}_{2} \\
\mathrm{r}=-0.600\end{array}$ & $\begin{array}{l}\text { Apelin }_{2}-\mathrm{ILC}_{2} \\
\mathrm{r}=0.486\end{array}$ & $\begin{array}{l}\mathrm{CK}_{5}-\text { Apelin }_{5} \\
\mathrm{r}=0.783\end{array}$ & $\begin{array}{l}\text { Apelin }_{2}-\mathrm{PT}_{2} \\
\mathrm{r}=0.474 \\
\text { Apelin }_{2}-\mathrm{PT}_{5} \\
\mathrm{r}=0.548\end{array}$ & \\
\hline IL6 & $\begin{array}{l}\mathrm{IL6}_{5}-\mathrm{PTX}_{4} \\
\mathrm{r}=0.581\end{array}$ & & $\begin{array}{l}\mathrm{CK}_{5}-\mathrm{IL6} 6_{3} \\
\mathrm{r}=0.700\end{array}$ & $\begin{array}{l}\mathrm{IL6}_{4}-\mathrm{PT}_{5} \\
\mathrm{r}=0.505\end{array}$ & \\
\hline CK & $\begin{array}{l}\mathrm{CK}_{4}-\mathrm{PTX}_{5} \\
\mathrm{r}=-0.842\end{array}$ & $\begin{array}{l}\mathrm{CK}_{2}-\mathrm{ILG}_{5} \\
\mathrm{r}=0.554\end{array}$ & & & $\begin{array}{l}\mathrm{CK}_{3}-\mathrm{VAS}_{4} \\
\mathrm{r}=-0.829 \\
\mathrm{CK}_{3}-\mathrm{VAS}_{5} \\
\mathrm{r}=-0.829\end{array}$ \\
\hline LDH & $\begin{array}{l}\mathrm{LDH}_{4}-\mathrm{PTX}_{3} \\
\mathrm{r}=-0.552\end{array}$ & $\begin{array}{l}\mathrm{LDH}_{2}-\mathrm{IL} 6_{3} \\
\mathrm{r}=0.641\end{array}$ & $\begin{array}{l}\mathrm{CK}_{4}-\mathrm{LDH}_{4} \\
\mathrm{r}=0.927\end{array}$ & $\begin{array}{l}\mathrm{LDH}_{4}-\mathrm{PT}_{5} \\
\mathrm{r}=0.484\end{array}$ & $\begin{array}{l}\mathrm{LDH}_{2}-\mathrm{VAS}_{3} \\
\mathrm{r}=-0.736 \\
\mathrm{LDH}_{2}-\mathrm{VAS}_{4} \\
\mathrm{r}=-0.783 \\
\mathrm{LDH}_{2}-\mathrm{VAS}_{5} \\
\mathrm{r}=-0.723 \\
\mathrm{LDH}_{5}-\mathrm{VAS}_{3} \\
\mathrm{r}=-0.728\end{array}$ \\
\hline
\end{tabular}

PT, peak torque; PTX3, pentraxin 3; IL6, interleukin 6; CK, creatine kinase; LDH, lactate dehydrogenase; VAS, visual analog scale.

resistance exercise group in patients with type 2 diabetes divided into different exercise groups [22], and after 6-week high-intensity interval training in hypertensive elderly individuals [23]. In the study carried out by Besse-Patin et al. (2014), it was found that apelin mRNA level increased in the skeletal muscle of obese individuals while the basal apelin level in the circulation remained the same at the end of an 8-week endurance training program. This finding was interpreted as the apelin expression is induced by exercise signaling pathways, can be secreted by human primary myotubes in vitro and can act as a new exercise regulator myokine with autocrine/paracrine activation [10].

In contrast with these studies, some others state that aerobic exercise decreases apelin levels. In these findings, it is thought that the positive correlation between apelin levels and BMI may have an effect; and the fact that basal plasma apelin level is higher in obese individuals compared with thin individuals or that exercise programs ending in weight or body fat loss decrease basal apelin levels may prove this hypothesis [11, 24].

In the only study examining the effect of acute exercise on apelin levels Shaibani, Shemshaki, and Hanachi (2011) examined the effect of single-session interval exercise on apelin levels in elite female runners $(n=15)$ prior to and following the exercise as well as at the 24th hour after the exercise [11]. Compared with the pre-exercise level, post-exercise plasma apelin level was observed to decline, while increasing significantly $24 \mathrm{~h}$ after the exercise $(p=0.001)$, which was not significantly different from the pre-exercise level [23].
In our study, on the other hand, there was no significant difference between the first and the repeated measurements of apelin level after the muscle damage protocol. The apelin levels observed after the exercise may have been caused by the nature of the exercise protocols performed.

It is reported that increased cardiorespiratory fitness elicits anti-inflammatory and cardio-protective effects, which reduce the risk of cardiovascular disease [25]. It is stated in the literature that basal PTX3 level, a marker of inflammation, is low in individuals with obesity and metabolic syndrome [26], whereas it is high in trained athletes [27] and that PTX3 levels go up with the chronic [25] effect of exercise given to obese or healthy individuals, which all support this idea.

Regular exercise could prevent cardiovascular morbidity by decreasing systematic inflammation, while excess inflammation can be reduced by anti-inflammatory protein PTX3 as well. In their study, Slusher et al. (2017) reported that although the basal PTX3 level of obese participants were lower after a single session aerobic exercise performed with $75 \%$ of $\mathrm{VO}_{2} \max$, it remarkably fell immediately after the exercise both in obese and normal-weight participants ( $\mathrm{p}<0.05)$, and went up to reach the basal values $1 \mathrm{~h}$ after the exercise [28].

Although no study has been found concerning the relationship between PTX3 and muscle damage in the literature, there is one study reporting that high-intensity exercises like cycling and resistance exercise, which go up gradually and are performed until voluntary exhaustion 
unlike aerobic exercise, increase plasma PTX3 values significantly [12]. Similarly, although no significant difference was found between measurements in our study, it can be seen that measurement results are higher immediately after (2) and $24 \mathrm{~h}$ after the exercise (3) compared with the pre-exercise levels (1) and this level decreased in the following 4th and 5th measurements, but did not fall back to the basal level (1).

In contrast with the anti-inflammatory effects of regular exercise, acute high-intensity and prolonged exercises are known to increase stress hormones as well as the number and functions of several immune cells, activate an acute-phase inflammatory response, increase the secretion of cytokines such as IL6 and inflammatory mediators and cause serious tissue damage [12,13]. It is reported that IL6 secretion, regardless of the exercise type, increases in direct proportion to duration and intensity after both acute and chronic exercises, which may reach 25-100 times of the basal level [29]. Correspondingly, the evident increase in plasma IL6 concentrations following different exercise protocols based on maximum eccentric contractions has been revealed by many studies [12, 13, 27]. In one study comparing the effects of three different types of exercise, it was shown that in high-intensity exercises like cycling (respectively 0.89-1.40-0.99 pg/mL) and resistance exercises $(0.66-1.03-1.06 \mathrm{pg} / \mathrm{mL})$ which increase gradually and are performed until volitional exhaustion, plasma IL6 levels measured before, immediately after and $1 \mathrm{~h}$ after the exercise went up significantly; however, no change was observed after the aerobic exercise session [12].

Although the finding that ER stress-induced inflammation causes IL6 increase $[7,8]$ supports the result of our study, the limited number of studies on IL6 and exerciserelated DOMS interaction in the literature restrict our discussion. For instance, as a result of muscle soreness protocol induced by eccentric exercise to 12 male participants, IL6 reached the peak level at the 6th hour [30]; while in another study, IL6 level peaked at the 24th hour after the eccentric exercise performed.

When the abovementioned studies are compared, both the basal and post-exercise IL6 levels we obtained are seen to be higher. This is considered to be caused by the effect of the positive correlation between IL6 and $\mathrm{VO}_{2}$ max, one of the markers of physical fitness [25] since the study participants consisted of athletes attending regular training.

Eccentric or unaccustomed exercise has been reported to induce muscle soreness and muscle damage. The structural damage of muscle cell is accompanied by the leakage of proteins such as CK and LDH out of the cell and into the circulation [31]. Significant serum CK elevations response to exercise may vary depending on the exercise type: In normal resting conditions, plasma CK is approximately $100^{\circ} \mathrm{IU} / \mathrm{L}$. However, following eccentric exercise, circulating levels of $\mathrm{CK}$ have been known to rise to 40,000 IU/L [32]. In our study, CK increase was 29, 132, 181 and $135 \%$ day by day, and the mean highest value reached was $12083^{\circ} \mathrm{U} / \mathrm{L}$. In other studies, after performing 50 maximal eccentric elbow flexor contractions, $55 \%$ of participants had CK elevations $>2000^{\circ} \mathrm{IU} / \mathrm{L}$ at 4 days after exercise; $25 \%$ had CK elevations $>10,000^{\circ} \mathrm{IU} / \mathrm{L} ; 13 \%$ had levels $>20,000^{\circ} \mathrm{IU} / \mathrm{L}$. Another study found significant increases in CK (approximate mean of $15,000^{\circ} \mathrm{IU} / \mathrm{L}$ ) after repetitive eccentric elbow flexor contractions in collegeage males [33]. Though It is possible that the CK response to exercise depends on the individual's physical characteristics or training background, CK peaks in 2-4 days whereas it is reported to reach its peak on the 5 th day after high-intensity eccentric exercise but at an earlier time after downhill running and is at a lower level than maximal and high-intensity eccentric exercise [34]. In our study, CK peaked at the 72nd hour. Based on this finding it is possible to mention muscle damage with the protocol performed. LDH is another marker of muscle damage and has been shown to increase following eccentric exercise [35]. In the present study, it is observed to reach its maximum level at the 72nd hour. Similarly, LDH plasma levels following a $130^{\circ} \mathrm{km}$ cycling race increases and may remain elevated for up to $72 \mathrm{~h}$ in trained cyclists [36]. Peak torque deficits are most pronounced $24-48 \mathrm{~h}$ following DOMS-inducing exercise. The duration of strength reduction is also greater following eccentric activity and may require up to 8-10 days to return to normal baseline levels. In the present study, isokinetic concentric knee extension PT values decreased $\%-17, \%-24, \%-27$, and $\%-18$ respectively according to the measurement of before the test. Exercise protocol, fibril type, contraction type, and the size of the muscle involved in the movement are known to affect the strength and muscle sensitivity caused by DOMS. Significant differences were shown in isokinetic eccentric PT of the elbow flexors at $0 \mathrm{~h}(43.5 \%)$, $24 \mathrm{~h}(38.8 \%)$ and $48 \mathrm{~h}(-32 \%)$ following repetitive eccentric contractions using an isokinetic dynamometer. The duration of strength recovery may have important implications for the athlete as an alteration in the strength ratio of agonist to antagonist muscle groups may contribute to an increased risk of injury [37].

Change ratios (\%) according to the first measurement reflecting the relative values were used in the correlation analysis because of different sizes and different units of the parameters in the study. The significant correlations found between CK and LDH, CK and LDH as well as PT and VAS as a result of repeated measurements in our study support the 
existence of DOMS created with exercise; and based on the correlations found between apelin and PT, IL6 and PTX3, CK, and between PTX3, IL6, apelin and CK and LDH, it can be considered that apelin, PTX3 and IL6, whose interaction with pathways have been revealed and which are also ER stress markers, can be used as DOMS markers in future studies as well.

The major limitations of the current study are the absence of concurrent assessment of ER stress-related marker proteins by in vitro methods, the absence of a control group, and uncontrolled design for the testing process. Although with limitations our study suggests a different way of understanding and discussion for ER stress in DOMS which may influence further studies needed in this field.

The current observations after the muscle damage test protocol suggest that ER is activated and ER stress occurred, due to increases in IL6, PTX3 and apelin levels. It is concluded that a single vigorous eccentric exercise should be avoided in harmful effect on health as parallel with Physical Activity Guidelines.

Acknowledgements: This study was not supported by any scientific research projects.

Research funding: None declared.

Author contributions: All authors have accepted responsibility for the entire content of this manuscript and approved its submission.

Conflict of Interest: The authors declare that they have no conflicts of interest, financial or otherwise.

\section{References}

1. Rutkowski DT, Kaufman RJ. A trip to the ER: coping with stress. Trends Cell Biol 2004;14:20-8.

2. Kaufman RJ. Orchestrating the unfolded protein response in health and disease. J Clin Invest 2002;110:1389-98.

3. Chen $\mathrm{H}$, Zheng $\mathrm{C}$, Zhang $\mathrm{X}$, Li J, Li J, Zheng L, et al. Apelin alleviates diabetes-associated endoplasmic reticulum stress in the pancreas of Akita mice. Peptides 2011;32:1634-39.

4. Jensen MP, McFarland CA. Increasing the reliability and validity of pain intensity measurement in chronic pain patients. Pain 1993;55: 195-203.

5. Castell JV, Gómez-lechón MJ, David M, Fabra R, Trullenque R, Heinrich PC. Acute-phase response of human hepatocytes: regulation of acute-phase protein synthesis by interleukin- 6 . Hepatology 1990;12:1179-86.

6. Mantovani A, Garlanda C, Doni A, Bottazzi B. Pentraxins in innate immunity: from C-reactive protein to the long pentraxin PTX3. J Clin Immunol 2008;28:1-13.
7. Li YX, Ren YL, Fu HJ, Zou L, Yang Y, Chen Z. Hepatitis B virus middle protein enhances IL- 6 production via $\mathrm{p} 38$ MAPK/NF-KB pathways in an ER stress-dependent manner. PloS One 2016;11: e0159089.

8. Liong S, Lappas M. Endoplasmic reticulum stress regulates inflammation and insulin resistance in skeletal muscle from pregnant women. Mol Cell Endocrinol 2016;425:11-25.

9. Hwang N, Kwon MY, Cha JB, Chung SW, Woo JM. Tunicamycininduced endoplasmic reticulum stress upregulates the expression of pentraxin 3 in human retinal pigment epithelial cells. Kor J Ophthalmol 2016;30:468-78.

10. Besse-Patin A, Montastier E, Vinel C, Castan-Laurell I, Louche K, Dray $C$, et al. Effect of endurance training on skeletal muscle myokine expression in obese men: identification of apelin as a novel myokine. Int J Obes 2014;38:707.

11. Shaibani S, Shemshaki A, Hanachi P. The effect of rast exercise on plasma levels of apelin and blood pressure in elite women runner. Qom Univ Med Sci J 2011;6:27-31.

12. Northoff H, Berg A. Immunologic mediators as parameters of the reaction to strenuous exercise. Int J Sports Med 1991;12:9-15.

13. Papanicolaou D, Petrides J, Tsigos C, Bina S, Kalogeras K, Wilder $R$, et al. Exercise stimulates interleukin- 6 secretion: inhibition by glucocorticoids and correlation with catecholamines. Am J Physiol Endocrinol Metab 1996;271:601-05.

14. Deldicque L, Hespel P, Francaux M. Endoplasmic reticulum stress in skeletal muscle: origin and metabolic consequences. Exerc Sport Sci Rev 2012;40:43-9.

15. Clarkson PM, Nosaka K, Braun B. Muscle function after exerciseinduced muscle damage and rapid adaptation. Med Sci Sports Exerc 1992;24:512-20.

16. Pereira BC, da Rocha AL, Pinto AP, Pauli JR, de Souza CT, Cintra $D E$, et al. Excessive eccentric exercise-induced overtraining model leads to endoplasmic reticulum stress in mice skeletal muscles. Life Sci 2016;145:144-51.

17. Fujie S, Sato K, Miyamoto-Mikami E, Hasegawa N, Fujita S, Sanada K, et al. Reduction of arterial stiffness by exercise training is associated with increasing plasma apelin level in middle-aged and older adults. PloS One 2014;9:e93545.

18. Banos J, Bosch F, Canellas M, Bassols A, Ortega F, Bigorra J. Acceptability of visual analogue scales in the clinical setting: a comparison with verbal rating scales in postoperative pain. Methods Find Exp Clin Pharmacol 1989;11:123-27.

19. Cockburn E, Hayes PR, French DN, Stevenson E, St Clair Gibson A. Acute milk-based protein-CHO supplementation attenuates exercise-induced muscle damage. Appl Physiol Nutr Metabol 2008;33:775-83.

20. Harrison AJ, Gaffney SD. Effects of muscle damage on stretchshortening cycle function and muscle stiffness control. J Strength Condit Res 2004;18:771-76.

21. Kadoglou NP, Vrabas IS, Kapelouzou A, Lampropoulos S, Sailer N, Kostakis A, et al. The impact of aerobic exercise training on novel adipokines, apelin and ghrelin, in patients with type 2 diabetes. Med Sci Mon 2012;18:CR290. https://doi.org/10.12659\% 2FMSM.882734.

22. Kadoglou N, Fotiadis G, Kapelouzou A, Kostakis A, Liapis C, Vrabas I. The differential anti-inflammatory effects of exercise modalities and their association with early carotid atherosclerosis progression in patients with type 2 diabetes. Diabet Med 2013;30:41-50. 
23. Shaibani S, Hanachi P, Refahiat MA. Effect of aerobic exercise on serum concentration of apelin, TNF $\alpha$ and insulin in obese women. Iran J Basic Med Sci 2012;15:1196.

24. Alavizadeh N, Mabhot MT. Effect of aerobic exercise with $75-85 \%$ of maximum heart rate on apelin and insulin resistance index in sedentary men. The Horizon of Medical Sciences 2017;23:55-61.

25. Miyaki A, Maeda S, Choi Y, Akazawa N, Tanabe Y, Ajisaka R. Habitual aerobic exercise increases plasma pentraxin 3 levels in middle-aged and elderly women. Appl Physiol Nutr Metabol 2012; 37:907-11.

26. Slusher AL, Mock JT, Whitehurst M, Maharaj A, Huang CJ. The impact of obesity on pentraxin 3 and inflammatory milieu to acute aerobic exercise. Metabolism 2015;64:323-29.

27. Hellsten Y, Frandsen U, Orthenblad N, Sjødin B, Richter EA. Xanthine oxidase in human skeletal muscle following eccentric exercise: a role in inflammation. J Physiol 1997;498:239-48.

28. Slusher AL, Shibata Y, Whitehurst M, Maharaj A, Quiles JM, Huang $C$ J. Exercise reduced pentraxin 3 levels produced by endotoxin-stimulated human peripheral blood mononuclear cells in obese individuals. Exp Biol Med 2017;242:1279-86.

29. Fischer CP. Interleukin- 6 in acute exercise and training: what is the biological relevance. Exerc Immunol Rev 2006;12:41.

30. MacIntyre DL, Sorichter S, Mair J, Berg A, McKenzie DC. Markers of inflammation and myofibrillar proteins following eccentric exercise in humans. Eur J Appl Physiol 2001;84:180-86.
31. Matsumoto K, Koba T, Hamada K, Sakurai M, Higuchi T, Miyata H. Branched-chain amino acid supplementation attenuates muscle sorenessi muscle damage and inflammation during an intensive training program. J Sports Med Phys Fit 2009;49:424-31.

32. Brown SJ, Child RB, Day SH, Donnelly AE. Exercise-induced skeletal muscle damage and adaptation following repeated bouts of eccentric muscle contractions. J Sports Sci 1997;15: 215-22.

33. Sudhakar S, Naiya A. Biochemical markers an indirect method for evaluating delayed onset muscle soreness among recreational athletes. Int J Biol Med Res 2012;3:1624-6.

34. Eston RG, Finney S, Baker S, Baltzopoulos V. Muscle tenderness and peak torque changes after downhill running following a prior bout of isokinetic eccentric exercise. J Sports Sci 1996;14:291-99.

35. Cheung K, Hume PA, Maxwell L. Delayed onset muscle soreness. Treatment strategies and performance factors. Sports Med 2003; 33:145-64.

36. Rodrigues P, Wassmansdorf R, Salgueirosa FM, Hernandez SG, Nascimento VB, Daros LB, et al. Time-course of changes in indirect markers of muscle damage responses following a $130 \mathrm{~km}$ cycling race. Rev Bras Cineantropom Hum 2016;18:322-31.

37. Evans DT, Smith LL, Chenier TC, Israel RG, McCammon MR. Changes in peak torque, limb volume and delayed onset muscle soreness following repetitive eccentric contractions. Int J Sports Med 1990;11:403. 